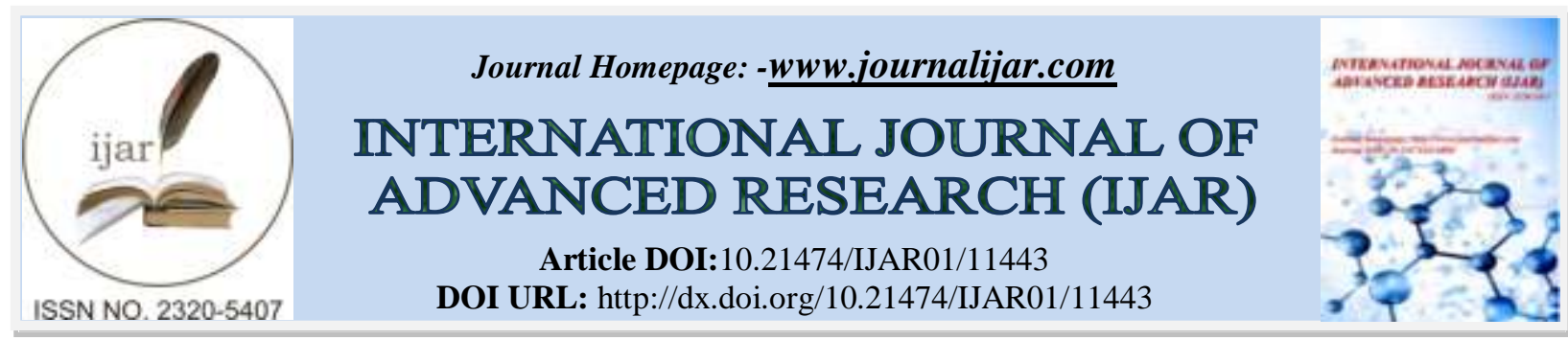

RESEARCH ARTICLE

\title{
THE IMPACT OF ISLAMIC CITIZENSHIP EDUCATION ON GRADE 6 STUDENTS' AWARENESS AND ATTIDUDES IN THE NEXT GENERATION SCHOOL IN QATAR
}

\author{
Mohd Abdul Alam ${ }^{1}$, Prof Dr. Ismail B.S Ahmad ${ }^{2}$ and Dr. Muhammad Junaid Mughal ${ }^{3}$ \\ 1. Doctoral Candidate Department of Curriculum and Instruction Kulliyyah of Education International Islamic \\ University Malaysia. \\ 2. Department of Language and Literacy Kulliyyah of Education International Islamic University Malaysia . \\ 3. Department of Usul ul-din \& Comparative Religion International Islamic University Malaysia.
}

\section{Manuscript Info}

Manuscript History

Received: 31 May 2020

Final Accepted: 30 June 2020

Published: July 2020

Key words:-

Islamization, Islamic Citizenship

Programme, Citizenship Education,

Education

\begin{abstract}
This article employs a qualitative inquiry method to understand the awareness and attitudes of three grade six students towards the Islamic Citizenship programme in the The Next Generation School hereto referred as TNG in Qatar. The TNG school strives to provide students with Islamic Values related to day to day lives while providing citizenship education in the form of Humanities subject. Through qualitative means, three grade six students were interviewed together with the Islamic Studies and Humanities subject teachers to understand their awareness and attitudes towards Islamic Citizenship Education. This was achieved by understanding in they had heard this term before, and if the understood the Islamic views on the subjects taught in the Humanities subject. The findings have revealed the students were mostly unaware of the Islamic Citizenship Education and of Islamic Perspective in the in Humanities subject. They seemed to show interest(attitudes) if Islamic perspective was discussed in the interviews regarding the Humanities topics. Recommendations have been provided for the school to create more robust processes to ensure students understand the Islamic Perspective in Humanities subject and take keen interest in the Islamic Citizenship Programme.
\end{abstract}

Copy Right, IJAR, 2020,. All rights reserved.

\section{Introduction:-}

This articlecaters to the background of the problem, related research questions, literature review, research methodology, research findings, recommendation and finally the conclusion. In this regards, the first part explains the background of the study, the problem statement, the purpose of the study, its significance, the related research questions and the research objectives. It also highlights the scope of the study, its limitations and the research methodology.

The second part, Literature Review, is broken down into four sub sections. The first section discusses the secular understanding of citizenship. The second section attempts to explain Islam's view of citizenship. The third section describes the secular concept of citizenship education while the final section attempts to comprehend Islamic concept of citizenship education. Under research methodology, the authors have elaborated on the process of 
research and identified the research subjects and research settings. Following this, the findings are presented and recommendations included.

\section{Background Of The Study:}

The purpose of education has increasingly become one of transferring information to students to be able to perform jobs in the fields of their interest. Students with minimal ethical standards are expected to make career-impacting decisions with a moral conscious. A United Kingdom study in 1998 by the Qualification and Curriculum Authority stated that students are increasingly distancing themselves from the social and political sphere of society.

"There are worrying levels of apathy, ignorance and cynicism about public life. These, unless tackled at every level, could well diminish the hoped-for benefits both of constitutional reform and of the changing nature of the welfare state. (QCA, 1998)"

This motivated the UK Education Council to create a new curriculum that would address citizenship issues in the school. Similarly, a study in South Africa (Ntsikelelo B. Breakfast, 2017) investigated that, "young people in postapartheid South Africa have no interest in politics." Now schools in Doha offering British curriculum are teaching citizenship education. Some Muslim individuals have experimented with "Islamic Citizenship" i.e. educating students about the social economic and political with Islamic values. One such school is The Next Generation School(TNG) hereto referred as "TNG" in Doha intends to "disseminate Islamic knowledge relevant to the day to day lives of the young children." Their aim is to provide British Curriculum together with Islamic Curriculum. This school teaches citizenship under the subject of Humanities in Grade 6.

However, the questions remain are these syllabuses fully equipping Muslim students to embrace the concept of Islamic citizenship education. The role of teachers in transferring the knowledge and the will to students to carry out their duties as responsible Muslim citizens cannot be over looked. This research will, therefore, investigate how successful TNG school has been in creating Muslim students who are aware of the social political and economic challenges in a society and look for their solutions in Islam.

\section{Statement Of The Problem:}

The purpose of Islamic citizenship education is to create morally and socially responsible citizens from Islamic point of view. These students should be independent and critically conscious, able to analyse the problem areas of the society and work towards their relevant solutions in the light of Islamic teachings. Research of secular citizenship education in Ireland (Duggan, 2015) and Zimbabwe (Namasasu, 2012) and Islamic citizenship education in Britain's Muslim schools (Al-Refai, 2007) suggest that not enough seriousness is allocated to citizenship education in schools.

The teachers teaching citizenship education often lack the motivation to teach this pertinent subject. According to the researches, the schools' management do not take keen interest in citizenship education. Generally, students and their parents often believe more attention should be given to main stream subjects such as mathematics, science, English and computing studies.

This research will examine the status of Islamic citizenship education in TNG in Doha. Islamic citizenship education is taught through two subjects, namely Islamic Studies and Humanities subject in grade 6 in TNG. This study will take a closer look into the Islamic citizenship through analysing the curriculum offered in this school looking for gaps in the syllabus and shortcomings of the current teaching methodology. The researcher will provide recommendations accordingly.

\section{Purpose of the study:}

The purpose of this research is to investigate to what extent teaching British and Islamic curriculum parallel has affected the worldview of students regarding the society and its issues. This study will examine whether the syllabus is able to impart social, economic and political knowledge to students with Islamic wisdom. The research will investigate whether the teachers are able to instil motivation and enthusiasm in students to be sincerely concerned about societies' issues and actively look for democratic means to solve the problem. This study will gauge the strengths and weaknesses of the syllabus and its teaching methodology. Interviews will be conducted with three grade 6 students and the humanities and Islamic Studies teachers. Subsequently, the study will offer recommendations to the syllabus and teaching methodology in the light of the research conducted. 


\section{Research questions:}

The central question would be to what extent is the current system of teaching Islamic studies and Humanities subject separately helping three grade six year students' in understanding the Islamic point of view in the Humanities subject.

There will be three main research questions that will deal with Islamic citizenship education curriculum, the content, the teaching methodology and the general school environment and attitude towards Islamic citizenship education.

How do the grade 6 students in Doha's secondary school define Islamic Citizenship Program hereto referred as 'ICE'?

1. Do you understand what ICE is?

2. Why do you study Islamic Studies and Humanities subjects?

3. Is there any link between Islamic Studies and Humanities subjects?

4. Have you covered the following issues in your ICE program?

a. Women Rights

b. Minority Rights

c. Labour Rights

d. Animal Rights

e. Activism

To what extent has the Islamic Citizenship Program changed the worldview of students regarding family and society?

1. Do you think there should be an influence of Islam in our everyday life?

2. Did you ever wonder what Islam has to say about the topics you learn in humanities class?

3. In Islamic studies, you are taught about praying fasting and wudhu. Are there any benefits to this apart from the reward we get for praying and fasting?

4. Are you participating in any community welfare program?

How did the senior students learn the Islamic Citizenship Program?

1. Do you think there is something missing in humanities or Islamic studies subject that you feel should be included?

2. Are you required to make presentations in class for Islamic Studies?

\section{Research Objectives:-}

The objectives of this study in TNG are as follows:

1. To investigate the goals of Islamic Studies and Humanities subjects.

2. To examine to what extent these goals have influenced the world view of students in regards with Islam.

3. To understand to what extend students three grade six students are understanding the Islamic Perspective in the Humanities subject British and Islamic curriculum are taught in parallel.

\section{Significance Of The Research:}

The direct beneficiaries of this research will be primarily the school management involved in the study. It will allow the management to identify the missing content in their Islamic citizenship education program(Humanities and Islamic Studies subjects) and inadequacies of the current teaching methodologies. It is hoped that the recommendations provided in this study will allow the school management to update the Islamic citizenship education program and correct the teaching methodology.

The second beneficiary will be the teachers teaching Islamic citizenship education who are struggling to identify the gaps in the syllabus and teaching methodology. The third beneficiary of this research will be the students of the schools involved in the research. An accurate and up to date Islamic citizenship education program will create the socio-economic and political literacy needed in Muslim students to identify issues in their society and rectify them in the light of Islamic teachings. The fourth group of beneficiaries will be all Islamic Schools committed to teaching Islamic citizenship education curriculum. 


\section{Limitations Of The Study:}

The research will use a case study approach. Geographically speaking, the study will be limited to one school in Qatar's capital city Doha. There are mainly two methods of research - Qualitative and Quantitative. Since this article is in requirement for a Qualitative Subject, only the qualitative research methodology is used. The study will delve into the matter of educational philosophies and models to a certain extent only. Thus philosophical discussions about various Islamic education models propounded by Al Attas(Al-Attas, 1997) such as the issue of ta'dib versus conventional Islamic education models will be remotely discussed. This is because the purpose of the research is not based on philosophy but citizenship education and curriculum. Thus, this study will investigate the gaps in the curriculum and syllabus of the Islamic Studies and Humanities subjects.

\section{Literature Review:-}

The authors have reviewed books on the secular concepts of citizenship and citizenship education followed by reviewing books on the Islamic view on citizenship and citizenship education.

The goal was to identify gaps in the secular as well as Islamic understanding of citizenship and citizenship education. In conclusion, the authors shall present a summary of some of the secular and Islamic citizenship education research conducted in schools.

\section{Secular Concept Of Citizenship:}

The author has reviewed Citizenship and Social Class by Thomas Marshall published in 1950.

In this book Citizenship and Social Class, Marshall defined citizenship as:

"...a status bestowed on those who are full members of a community. All who possess the status are equal with respect to the rights and duties with which the status is endowed. There is no universal principle that determines what those rights and duties shall be, but societies in which citizenship is a developing institution create an image of an ideal citizenship against which achievement can be measured and towards which aspiration can be directed" (Marshall, 1992).

Marshall has provided the fundamentals of modern democratic citizenship that sub categorise citizenship into three sets of rights: civil, political and social. He defines civic rights as:-composed of the rights necessary for individual freedom - liberty of the person, freedom of speech, thought and faith, the right to own property and to conclude valid contracts. Political rights have been identified as:-the right to participate in the exercise of political power, as a member of a body invested with political authority or as an elector of such a body.

The final set of social rights have been explained as:-from the right to a modicum of economic welfare and security to the right to share to the full in the social heritage and to live the life of a civilized being according to the standards prevailing in the society. The problem with Marshall's understanding of a citizen was that he has assumed society is heterogeneous only. As Isin and Wood have pointed out (Isin, 1999), Marshall has underestimated the importance of gender, race and ethnic inequalities. For Marshall, society was divided into rich and poor class only. Therefore, proponents of gender equality, multiculturalism and environmentalism poured into the concept of citizenship their respective views. The second book reviewed is Inclusion and Democracy by Iris Marion Young published in 2000. (Young, 2000).She has opined that an ideal form of citizenship is to recognize the "social differentiations" and the encouragement of differently situated groups" so that each ethnic or religious community feels that it is being "heard".

The problem with this book is that while it upholds the value that society must accept people from all communities, it exhorts that people should realise the importance of setting aside their personal "moral commitments". She argues that citizens must be willing to be "open to having their own opinions and understandings of their interests change in the process". This is a good suggestion yet it can hold problems for sections of society that model their way of life based on religious teachings. For example, the issue of Niqab; Is a French citizen not fulfilling his duties as a citizen by wearing a Niqab that she believes is a central to her religion?" How would Young categorise such a citizen? Thus, the author suggests of "real inclusive democracy" that allows difference of personal opinion in a true heterogeneous society. While the first two books have dealt with the definition of a citizen in depth, many new issues are plaguing the society that need to be addressed. Natural disasters, is one of such issues. The negative and sometimes disastrous effects of climate change are very visible in contemporary times. 
The third book reviewed in this category is aptly titled Citizenship by Keith Faulks (Faulks, 2000). The benefit of this book is that it introduces the concept of citizenship and highlights the contradictions in the understanding of citizenship. Keith has proposed that an ideal citizen should be concerned about climate change and should consider the environment when deciding upon any course of action. Many countries have complex cultural identities where each ethnic or religious community is vying for resources and appreciation of their fundamental rights. While the book critiques liberal context of citizenship it fails to provide any clear alternative. Keith calls his alternative to liberal citizenship, 'Postmodern Citizenship'. It is vague and ambiguous, as it does not stipulate who has priority; the state or the individual since it stresses on the importance of both. The author proposes to fill this gap by stating that the state must have priority over the personal freedom of a citizen as long as the state is guided by 'revealed knowledge'. The idea of 'revealed knowledge will be explained in the coming chapters'.

\section{Islamic Concept Of Citizenship:}

Classic, modern and contemporary Muslim scholars have discussed the Islamic concept of an ideal citizen in detail. Al-Mawardi's idea of a state (Al-Mawardi)is one that stringently follows the dictates of Sharia. Hence, an ideal citizen is one who adheres to the principles of the Sharia and strives to create a society through government administration where there is a dominance of Good and general obedience of the laws of Islam. Thus it is clear that an ideal citizen must have a deep understanding of Islamic principles of life. Mawardi asserted the importance of democracy when he mentioned that it is the people who would elect the Imam based upon consensus and thus termed the first forty years of Islamic caliphate as true form of Islamic democracy. The problem with Al-Maward's concept of an ideal citizen is that it does not incorporate modern issues of environmentalism and multi-cultural citizenship issues. This book was written to be a general guideline for administration only. Yet it does inform us of the earliest ideas of an ideal Muslim citizen. Ibn Khaldun has touched on the concept of a multi cultural citizen in his own way as was the modulus operandi of classic scholars. It was not necessary then to attach specific names to various concepts of citizenship as contemporary scholars do now.

Ibn Khaldun opines in his magnum opus Muqddamah(Ibn Khaldun) that human beings are interdependent and thus cooperation is necessary for survival. He succinctly sums up his theory of citizenship in the words, "man is a citizen by nature". On cooperation Ibn Khladun says, "this association is necessary for mankind, otherwise their existence and God's will to make the world habitable with them would not be perfect". Interestingly, social studies courses in England and Zimbabwe also place great importance on appreciating the value of interdependence in the human society (Namasasu, 2012). However, Ibn Khaldun points to the importance of "reflection" enabling a human being to live. This view of a reflecting citizen matches closely to Freiro's theory of critical consciousness and transforming intellectual as discussed above.

Ibn Khaldun lived in a Muslim Monarchy but the modern period saw formation of Muslim democracies such as Pakistan. How does a modern ideal Muslim citizen look like? Mawdudi saw an ideal citizen as one who did not differentiate between the religious and political. He has written much about the importance of being "politicized" in the sense of being an active, participating citizen of an Islamic state. Maudoodi's idea of an ideal citizen closely resembled that of Al Mawardi where it was the duty of the state to implement the Sharia and an ideal citizen was one who would push for constitutional reforms to create such an Islamic state in Pakistan. (Maudoodi, 1960)". The problem with AlMawardi, Ibn Khaldun and Maudoodi is that while they have spoken at length about the duties of an ideal citizen in a Muslim country, the concept of an idea Muslim citizen in a non-Muslim country has been overshadowed. This gap has however been filled by contemporary Muslim scholar Tariq Ramadan who has lived most of his life in non-Muslim countries. Ramadan states that Muslims living in non-Muslim majority nations have been "sent back to the essential teachings of Islam" so that they can contribute to "promoting good and equity within and through human brotherhood" by bringing the strengths of the Islamic message to their mostly non-Muslim societies (Ramadan, 1999).

In other words, Muslims need to contribute to the universal good values in non-Muslim nations positively influencing the social economic landscape of the country they are living in. As long as the government does not oppose the Islamic way of life, Muslims are obliged to be loyal citizens in non-Muslim states. Their goal should be to be "in Europe but at home." To be a Muslim in Europe ideally "means to interact with the whole of society." Ultimately, a European Islam should emerge, as witnessed in African or Asian Islam. While early Muslim scholars have asserted that an ideal citizen is one who abides by the Sharia, strives towards creating an Islamic state and is pro-democracy, Ramadan have suggested that an ideal citizen in a non-Muslim society is one who ensures that the state does not interfere with his/her Islamic way of life and indeed interacts with the non-Muslims exchanging ideas. 
The major issue with Ramadan's theory is that it does not exhort his Muslim reader living in a non-Muslim country to enthusiastically pursue dawah activities. Muslims are not supposed to be living in non-Muslim countries only to be able to make a decent living and be undisturbed to practice their religious duties. An ideal Muslim in a nonMuslim society is one who actively preaches the message of Tawhid and works toward influencing policies with Islamic guidance. This is research will thus provide a model that will incorporate issues faced by Muslims living in non-Muslim countries as well as push for the inclusion of environmentalism and multi culturalism aspects into the concept of an ideal Muslim citizen.

\section{Secular Citizenhsip Educational Thought:}

The most important book reviewed in this section is Pedagogy of the Oppressed by Paulo Freire published originally in Portuguese language in 1968. The researcher has reviewed its English translation first published in 1970. According to Freire a literate is one who understands the cultural politics and is concerned about the empowerment of people through the promotion of social and political change (Freire, 1970). The purpose of education according to Freirean pedagogy challenges both students and teachers "to empower themselves for social change, to advance democracy and equality" (Freire, 1970). Freire advances his philosophy of schooling quite succinctly. He declares that an educational system that places greater importance on "rational economic actors follows the "banking" concept of education, a form of education that is gauged by measurement of how much information has been transmitted to a student (Freire, 1970). I quote Freire to explain his idea of the "banking" culture in schools today:

"becomes an act of depositing, in which the students are the depositories and the teacher is the depositor. Instead of communicating, the teacher issues communiqués and "makes deposits" which the students patiently receive, memorize and repeat. The more students work at storing the deposits entrusted to them, the less they develop the critical consciousness which would result from their intervention in the world as transformers of that world." (Freire, 1970). Freire proposed an alternative form of schooling that emphasizes the humanization and conscientisation of the student based on a dialogic form of communication. "The teacher is no longer merely the-one-who-teaches, but the one who is (himself/herself) taught in dialogue with the students, who in their turn while being taught also teach." (Freire, 1970). Freire has also pointed out the necessity of a teacher being a "transforming" intellectual who critically analyses himself/herself and "wants to change the world" and thus inspires the same spirit in his/her students. Freire states that humanized students are sensitive to the needs of the less fortunate in the society and champion the rights of the needy. The fundamental problem, according the researcher with this book is that it bases its argument on the concept of dialectical materialism. Dialectical materialism is a Marxist theory that political and historical events result from the conflict of social forces and are interpretable as a series of contradictions and their solutions. Not every problem of school education is a strategy by the rich elite class to be purposely keep the poor peasant, labor class ignorant while floating the idea that they are being educated. We can derive useful theories form Freire's book but it cannot be a basis to critique education in schools where Freire's idea of society division is not fully practiced. The works of Remy and Osley and Starkey have also been reviewed in this research to understand the role of citizenship education in training students to be responsible members of society. According to Remy, citizenship education prepares learners to address three fundamental questions (Remy, 1979):

1. Under what conditions should I (as a citizen of a family, or a city or a nation of the global community) be loyal to and be proud of my group and when should I be critical?

2. Under what conditions should I (as a citizen of a given group) comply with the laws, rules or norms of that group and support its political authorities, and when should I defy rules and authorities?

3. Under what conditions should I (as citizen of a given group) actively participate in the political life of the group and if necessary sacrifice for the common good and when should I defend or assert my private interests or withdraw to nurture my private life?

Remy's work does not have any place for God. The book assumes that sovereignty of the state belongs to the ruling party. Most of the questions that Remy has raised do not even arise in an Islamic state. As servants of Allah (swt), a Muslim citizen is bound to defend his country and religion and sacrifice his very life in this cause. Personal freedom does not have priority over state laws influenced by Islamic revealed knowledge. The author will attempt to fill in the gaps left by Remy's work. A third very important book reviewed in this section is Tristan McCowan's 2009 published book, Rethinking Citizenship Education: A Curriculum for Participatory Democracy. In this book (McCowan, 2009), McCowan asks if students are being equipped with necessary knowledge and polities to actively participate in the democratic system of their country to produce positive changes in the society. He has illustrated in his book how students are not aware of their civic responsibilities. He blames repetitive debates and less about the actual process of instilling awareness and the will in students to participate in a democratic country. It is a must read 
book simply because it details creative yet fully research based models to teach citizenship education. While the book includes the concept of citizenship education from various countries such as Asia, Europe and North America, it does not address two main issues. Firstly, what about students from various countries studying in an international school. Which idea of citizenship education do they follow then? As expatriates, can one really participate in the political system of a foreign country? Secondly, what if the student is studying in a country that is a monarchy but free and fair administrative procedures? How does one go about eradicating problems in a monarchy? My thesis will provide answers to these questions so that foreigners studying in an international school can participate in some level with government authorities to bring about positive change in the country.

\section{Islamic Citizenship Educational Thought:}

Much has been written on Islamic Education. Ashraf (Ashraf, 1985) separates between Islamic religious knowledge and "technical" education. Ashraf has labelled western education as "secularist-modernist" idea of knowledge and stressed the importance of "acquired knowledge" that is revealed to mankind by Allah (swt). Ashraf has urged Muslims to take back education "from the hands of western educationists" who do not hold the will of God as central in implementing social economic policies in the state. The problem with Ashraf's theory of Islamic education is that he is comfortable with the Islamic packaging of Greek concept of knowledge. This is an issue as two branches of knowledge whose fundamentals are opposite can meet eye to eye at certain level but cannot connect at deeper levels. In this regards, Al-Attas(1997) has been bold to almost separate Western Secular Education and clearly define Islamic concept of education.

Al-Attas(1997) has defined Islamic education as, “"Recognition and acknowledgement, progressively instilled into man, of the proper places of things in order of creation, such that it leads to the recognition and acknowledgement of the proper place of God in the order of being and existence.". The conventional model of Islamic Education is termed as Tarbiyyah meaning to educate. However, according Al-Attas, the Tarbiyah term does not provide a holistic approach to education. It is similar to the Western term for education, 'educere' that has physical and material connotation only. Al-Attas proposed Ta'dib that includes the necessary moral and spiritual requirements as well. The purpose of Islamic education should be to produce a good Muslim. In Al-Attas words, a man of "Adab".

Al-Attas defines a man of adab as, "the one who is sincerely conscious of his responsibilities towards the true God; who understands and fulfils his obligations to himself and others in his society with justice, and who constantly strives to improve every aspect of himself towards perfection as a man of adab." (Al-Attas, 1997). While this is a very holistic model of education, it does not evolve into a practical model of teaching in classrooms. McCowan lamented earlier about this problem. While McCowan does provide a practical model with real life examples of teaching citizenship education in classes, it does not have the Islamic base to it. While Al-Attas provides the Islamic theoretical framework, it does not a practical guide to teaching in the real life situations. This is where my thesis comes into play. I will propound a theoretical base for Islamic citizenship education and yet provide a practical guide for teaching it in every day scenarios.

\section{Research Methodology:-}

This study will adopt the qualitative approach. It will study the concept of citizenship education analysing the curriculum and teaching methodology. It will also use survey method for collection of data on some issues such as political, social and economic. A checklist will be used to investigate if the topics of interest have been included in the syllabus.

Three grade six students, Islamic Studies teacher and humanities teacher for Grade 6 will be interviewed (questions will be provided) to gauge the interest and seriousness amongst the teachers, school administration and parents regarding Islamic Studies subject and Social Studies subject. When evaluating the implementation, the authors prefer the naturalistic and participant oriented approach. This is because it is necessary to speak to the teachers, students, parents and the school administration to understand how much value is being assigned to citizenship education subjects. If any of the four are not serious about the subject, then the effectives of the subject will be marginalized. It is also very necessary to study in depth the day to day teaching method of the teachers to identify what they are doing is right and where there is a need for improvement. For the qualitative phase of this study, the one-to-one standardised open-ended interview is considered as an appropriate research method to access the perspectives and perceptions of the stakeholders of the secondary schools, that is, students, parents, teachers and school Principals. 
The intention is to facilitate each member of each stakeholder group in recounting their personal experiences, thoughts and expectations regarding key aspects of citizenship education. First a pilot study was conducted. It involved just one student. Several observations were made and the questions were readjusted accordingly. The observations of the pilot study will be included in the appendix.

The size of the sample was one school where Islamic Citizenship education is taught in the form of social studies(Humanities Subject) and Islamic studies. It is 'The Next Generation School'. The following roles have been identified to be interviewed: Principal; Social Studies and Islamic Studies Teachers; Students and Parents. The sample size is as follows: Three students from grade six and one Islamic Studies teacher and one humanities teacher.

\section{Research Findings:}

Islamic Citizenship Education is taught through subjects Islamic Studies and Humanities. The humanities subject comprises of 12 chapters six of which are history and six of which are geography. The Islamic Studies Subject for grade six is teaching on the 5 pillars of Islam, Islamic Morals and simple Hadeeth.

The informants interviewed were total five: three grade six students, Farha, Shereena and Hala. The Islamic studies teacher for grade six, Alma and Humanities teacher Arwa. The names have been changed.

All five informants were interviewed on their understanding of Islamic Citizenship, how it influences their worldview and the challenges in learning this pertinent program. The value behind studying Islamic Studies and Humanities subject, the interlink/overlap between Islamic Studies and humanities subject and challenges faced learning/teaching Islamic Citizenship in classes.

The interviews were conducted in the premise of TNG. Each interviewee was interviewed for approximately $20-25$ minutes. It was a one on one face to face interview all in the English language. A voice recorder was used for this purpose. Interviews were transcribed by using standard interview transcription format. The 7 Column Main Idea generation format(Table 1.0-Table 1.5) was used to capture the main ideas presented/emerged in the interview.

A color coding technique was used to group similar ideas.

Eight main critical ideas emerged form the interview:

1. Students have a very basic understanding of Islamic Citizenship Education.

2. Students understand on a very basic level that there can be a connection between Humanities subject and Islamic studies subject.

3. There is no attempt to teach Humanities subjects with an Islamic worldview. Students fail to view historic events and geographic issues within the light of Islam.

4. Students have very basic knowledge of terms like women rights and animal rights and have participated in community welfare programmes(activism).

5. Labor Rights and Minority rights are not being taught to students.

6. There is very little evidence of efforts to understand Islamic teachings from not only the point of view of rewards but form the view of impact on personal self-growth as human being and also from the macro societal level.

7. Students believe nothing extra needs to be added to the subjects.

8. Presentations are included Islamic Studies subjects.

Regarding the first idea, students seem to have a basic understanding of what Islamic Citizenship education is. The realise it has "something to do with Islamic knowledge and society". I understand that probably the term Citizenship or Islamic Citizenship is not being used in the school formally. The problem is that students don't seem to be aware of the term citizenship education itself whereas since 2000 it is an integral part of the British Curriculum. The Personal Social and Health Education learning modules are taught because of the citizenship education module. Learning to live in harmony with one another or studying leadership traits is also part of citizenship education. The teachers have said that they have heard of the term. This is not enough and it is a problem. The teachers have said that they have heard of the term. This is not enough and it is a problem. The second and third critical ideas are interlinked. Students seem to have a very faint idea of a connection or overlap between Humanities and Islamic Studies. In otherwordsstudents do not see Islam outside a set of rules regarding monotheism and do's and don'ts. The second and third aim of curriculum is, "To disseminate Islamic knowledge relevant to the day to day lives of the 
young children. To enable children to acquire knowledge of the world and to think creatively, use decision making tricks and solve problems which occur in day to day life." What kind of knowledge of the world are these students supposed to acquire secular or with an Islamic perspective? Is our day to day life influenced by the social political and economic surroundings of our society? If yes, then shouldn't know the Islamic perspective on these factors if the aim is really to "disseminate Islamic knowledge relevant to the day to day life". As per the interviews conducted with humanities teacher, there is no instruction from higher management to teach students about what would have been ideal in history according to Islam. Indeed mistakes of past historic figures is discussed but without discussing what Islam would have to say about it.

One positive revelation of the interview is that women rights, animal rights and a sense of activism is being taught in the schools. Although it is very limited, there is mention of women and animal rights in Islamic studies class. Both Islamic teacher and humanities teachers have tried to instill a sense of activism in students. The Islamic studies teacher instructed students to create charity boxes and collect charity and distribute to the needy while the humanities teacher is running a project where students are working on projects about investigating the impact of technology in our life and what can be done about its harms. The question however is, can these random initiatives instill a habit of relentless activism in students?

The fifth point to be noticed is that students are not being taught about labor rights and minority rights. One of the goals of citizenship education is to create students who are aware of the fundamental basic rights of human beings and are motivated to fight for these rights. Qatar has been under a lot of pressure for its labour rights issue. In order to win the World Cup 2022 bid, Qatar has looked at several of its labor issues including salary payment on time for laborers and ease of exit. Students in TNG are not being taught about labor rights or minority rights. After women and laborers, minorities are the most marginalized section of the society. Students needs to be aware of how serious these two right issues are and include it in their syllabus. The sixth main critical idea that emerged from the interview is that students are being taught about the rewards of practicing the five pillars of Islam and following the Islamic injunctions. The personal and social benefits related to practicing Islam are not really discussed in the class. I questioned all three students and the Islamic studies teacher. The students were not able to mention any benefit of fasting or praying other than reward while the Islamic teacher gave very generic replied to the benefits of prayers. I had to directly as about any social benefit of prayer and then I received a short unsatisfactory reply.

The seventh and eighth critical idea were in relation to the challenges students faced in studying Islamic Studies and humanities subjects. The students did not believe anything was lacking in the Islamic Studies and Humanities subject. The students mentioned that presentations were required of students to display what they have learnt in the classes.

\section{Recommendations:-}

Each of the critical main ideas that emerged from the interview are serious issues. In the light of my literature study, I would recommend the following steps be taken:

\section{Islamic Citizenship Education training workshop:}

1. Higher management conducts an Islamic Citizenship Education awareness program to thoroughly introduce to teachers the concept of Islamic citizenship education.

2. A one day training workshop can be conducted explaining to teachers how the idea of citizenship education emerged and under what conditions.

3. The importance of citizenship education must be communicated to teachers.

4. The reason behind attaching Islamic worldview to citizenship education must be communicated to teachers. They need to understand the pros and cons of secular citizenship education and Islamic citizenship education.

5. A one day Islamic Citizenship education awareness day must be in conducted in the school for students and parents to understand the importance of this concept.

\section{Islamization of Knowledge and Education training workshop:}

1. Teachers followed by students should be exposed to the ideas of Islamization of Knowledge and Education. Works of Al Attas (Al-Attas, 1997) must be circulated amongst the teachers so they understand why socially relevant subjects like humanities need an Islamic perspective as well. 
2. Humanities textbooks must have a section on the Islamic perspective of the historical events. It seems there is a class discussion on the mistakes of historic figures but without an attempt to understand what would have been an Islamic

\section{Human rights:}

1. Grades 7 and upwards for Humanities must include devoted chapters on women rights, animal rights, labour rights and minority rights.

2. The history of generational discrimination must be taught to students so they understand where rights activists are coming from.

3. Another benefit of teaching about generational discrimination is that students understand that these biases are deeply entrenched into the society and will not be solved by simple steps.

\section{Understanding Islam comprehensively:}

The Islamic studies teacher can be placed on a training course where she can go through the work of Mawdoodi(A.A., 1985) on the five pillars of Islam and Tawhid must be introduced to her.

\section{New format for presentations:}

1. Humanities class presentations should include what Islamic worldview on the mater being presented. For example, if the presentation is about Mughals fighting one another for throne, the Islamic view on this should be explained by students.

2. Islamic studies class presentations should include references to how following Islam noly only benefits us in Akhirah but in this world as well in terms of our jobs, family life, personal well being and even on state level.

\section{Conclusion:-}

The aims of this school at leasts in theory are very similar to the idea of Islamic Citizenship. Being a British School, it is necessary for the school to adopt the Citizenship program as it is an integral part of its curriculum. Since it's very serious about teaching schools Islam in a comprehensive manner, there is no harm if the school attaches the term Islamic to its citizenships program, thereby calling it Islamic "Citizenship". A training workshop introducing the concepts of citizenship education and Islamization of knowledge and education is necessary for the teachers to understand the due importance of Islamic Citizenship education and teach it in the classrooms. According to the curriculum aims of The Next Generation school located in Doha, it intends "To enable pupils to develop moral sensibility through carefully taught Islamic values," and "To disseminate Islamic knowledge relevant to the day to day lives of the young children. To enable children to acquire knowledge of the world and to think creatively, use decision making tricks and solve problems which occur in day to day life." Two core subjects that can enable this is Islamic studies and Humanities subjects. The school is indeed taking Islamic Studies curriculum seriously but it is very traditional based. It is teaching students about the fiqh related to Islam and how this translates into rewards. Students are not learning about the rich benefits that Islam can have on a student's personal well being, family life, social life and how Islam can impact at the state level as well. This can be rectified by training the teacher on as explained earlier.

The Humanities teacher is teaching history through a very secular perspective. If the aim of the curriculum itself is "to disseminate Islamic knowledge relevant to the day to day lives of the young children" then aren't the chapters being taught in humanities class related to the person's everyday life. And if so, Islamic knowledge concerning those aspects in humanities text book chapters is not being taught to students. There must be instruction form higher management to teach students about the Islamic perspective on the things they are learning in History as this will shape their worldview.

\section{Bibliography:-}

1. A.A., M. (1985). Let Us Be Muslims. Leicester: The Islamic Foundation.

2. Al-Attas, M. (1997). The Concept of Education in Islam: A Framework for an Islamic Philosophy of Education . Library of Islom Ltd.

3. Al-Mawardi, A. H. (n.d.). The Laws of Islamic Governance. (A. Yate, Trans.) London: Ta-Ha Publishers.

4. Al-Refai, N. (2007). Muslim schools and the teaching of citizenship. University of Huddersfield.

5. Ashraf, A. (1985). New Horizons in Muslim Education. Hodder \& Stoughton Ltd. 
6. Duggan, P. (2015). Citizenship education in Irish secondary schools: the influence of curriculum content, school culture and stakeholder perspectives. Dublin: University College Cork, Ireland.

7. Dwyer, P. (2010). Understanding Social Citizenship: Themes and Perspectives for Policy and Practice. UK: The Policy Press.

8. Faulks, K. (2000). Citizenship. London and New York: Routledge.

9. Freire, P. (1970). Pedagogy of the Oppressed. New York Publisher.

10. Ibn Khaldun, A. (n.d.). The Muqaddimah. Princeton University Press.

11. Isin, E. a. (1999). Citizenship and Identity. Thousand Oaks and New Delhi: Sage Publications.

12. Jefferson, T. (1810, September 20th). Document 8 Thomas Jefferson to John B. Colvin. Letter to John B. Colvin, 11:146. Retrieved from http://press-pubs.uchicago.edu/founders/documents/a2_3s8.html

13. Marshall, T. (1992). Citizenship and Social Class. Citizenship and Social Class. Pluto Press.

14. Maudoodi, A. (1960). The Islamic law and constitution. Lahore: Islamic Publications.

15. McCowan, T. (2009). Rethinking Citizenship Education: A Curriculum for. London.

16. Namasasu, O. (2012). THE QUALITY OF CITIZENSHIP EDUCATION IN HARARE PRIMARY. Harare: UNIVERSITY OF ZIMBABWE.

17. Ntsikelelo B. Breakfast, G. B. (2017). Political apathy amongst students: A case study of Nelson Mandela Metropolitan University. Capte Town.

18. Osler, A. \&. (2003). Citizenship, human rights and cultural diversity. In A. Osler (Ed.) Citizenship and democracy in schools: Diversity, identity, equality. Trent: Trentham Books.

19. QCA. (1998). Education for Citizenship and the Teaching of Democracy in Schools. Final Report of the Advisory Group on Citizenship (The Crick Report). London.

20. Ramadan, T. (1999). To be a European Muslim. United Kingdom: Islamic Foundation.

21. Remy, R. (1979). Handbook of basic citizenship competencies. Washington DC: National council for the Social Studies. .

22. Shor, L. (1993). Education is Politics: Paulo Freire's Critical Pedagogy. London and New York: Routledge.

23. Young, I. (2000). Inclusion and Democracy. Oxford and New York: Oxford University Press. 